\title{
Cost of Preliminaries of Construction Projects for Civil Infrastructure Works in Malaysia
}

\author{
Abdul Aziz Abas, Zulhabri Ismail*, Faridah Ismail, Ruslan Affendy Arshad \\ Faculty of Architecture, Planning and Surveying, Universiti Teknologi MARA (UiTM), Shah Alam, Selangor, Malaysia \\ *Corresponding author: zulhabri@salam.uitm.edu.my
}

\begin{abstract}
The preliminaries bill for quantities of a construction project provides general information, mandatory instructions, and setup running costs for a construction contract period. The bill is crucial and arbitrary in nature. The aim of this study is to verify the percentage difference between preliminaries of building and civil infrastructure works. The objective is to assist players in the construction industry to differentiate the preliminaries percentage between both types of civil works. As such, the decision maker would be able to make a more reliable budget allocation, particularly for the civil infrastructure project. 25 tender evaluation documents from six civil infrastructure tender evaluation exercises were analysed. The average preliminaries were derived based on the qualitative method using content analysis. The preliminaries for building works established by previous researchers and civil infrastructure derived from this study were compared to verify any significant deviation. The statistical analyses using Boussabaine's and standard deviation were compared to establish the most reliable result. The study concludes that the preliminaries of civil infrastructure works are between $3.26 \%$ and $6.38 \%$ as compared to that of building works between $3.60 \%$ and $7.94 \%$. Consequently, the preliminaries of civil infrastructure work are lower up to $16.5 \%$ as compared to the building work. Despite the differences, average preliminaries are higher than 3\% but not exceeding $10 \%$ of the tender sum for both types of construction works. Thus, the findings provided significant updates for the Malaysian construction industry.
\end{abstract}

Keywords: Civil infrastructure; building work; preliminaries; tender evaluation

\begin{abstract}
Abstrak
Senarai persiapan untuk projek pembinaan menyediakan maklumat-maklumat am, arahan-arahan khusus, dan kos-kos persediaan di sepanjang tempoh kontrak. Senarai ini adalah penting dan berunsur timbang-tara. Matlamat kajian adalah untuk mengesahkan adanya perbezaan peratusan persiapan di antara kerja-kerja bangunan dan infrastruktur sivil. Objektifnya adalah untuk membantu pemain-pemain industri pembinaan membezakan peratusan persiapan di antara keduadua jenis kerja sivil. Oleh itu, pembuat keputusan boleh memutuskan sesuatu peruntukan bajet dengan lebih tepat, khususnya untuk projek infrastuktur sivil. 25 dokumen-dokumen penilaian dari 6 tender untuk kerja infrastruktur sivil telah dianalisa. Purata peratusan persiapan telah diperolehi berdasarkan kaedah kualitatif menggunakan analisa kandungan. Persiapan untuk kerja-kerja bangunan yang diperolehi dari pengkaji-pengkaji yang terdahulu dan infrastruktur sivil yang diperolehi dari kajian ini telah dibandingkan untuk mengesahkan sebarang perselisihan. Analisa-analisa statistik menggunakan tatacara Boussabaine dan sisihan piawai telah dibandingkan untuk memperolehi keputusan yang lebih dipercayai. Kajian menyimpulkan peratusan persiapan infrastruktur sivil adalah di antara 3.26\% dan 6.38\% dibandingkan dengan kerja bangunan yang di antara 3.60\% dan 7.94\%. Akibatnya, peratusan persiapan infrastruktur sivil adalah lebih rendah sebanyak $16.5 \%$ dibandingkan dengan kerja bangunan. Walaupun adanya perbezaan, purata persiapan adalah melebihi $3 \%$ tetapi tidak melebihi $10 \%$ dari nilai tender untuk kedua-dua jenis pembinaan. Oleh itu, penemuan kajian telah menyumbang maklumat terbaharu untuk industri pembinaan Malaysia.
\end{abstract}

Kata kunci: Infrastruktur sivil; kerja bangunan; persiapan; penilaian tender

(C) 2017 Penerbit UTM Press. All rights reserved

\subsection{INTRODUCTION}

Preliminaries are integral components of the quantities bills for a construction project (Ghani, 2006). The cost of preliminaries varies between contractors depending on the complexity of project. The accuracy of preliminaries is of interest for many researchers as it contributes significantly to the overall construction cost. Ghani (Ghani, 2006) found difficulty in pricing the preliminaries and usually ended up with a large variation since the contractors used their own interpretations and approaches. International Construction Market Survey 2016 (Turner \& Townsend, 2016) reveals that the preliminaries for Malaysia constitute some $10 \%$ of the tender sum. Generally, preliminaries for building works are used to represent the construction industry, despite building and civil infrastructure works entail separate scopes. However, preliminaries for the civil infrastructure works are not explicitly defined, thus has spurred concern for the author to analyse and establish the percentage based on Malaysian construction industry context.

This study assessed the present pricing trend by the Construction Industry Development Board's (CIDB) registered contractors of grade G7 category CE for civil works. The Construction Industry Development Board (CIDB, 2016) specifies Grade G7 being the highest 
grade entails an unlimited tender capacity, and is permitted to participate in National projects . As such it provides a strong outreach to the contractors. Grade G7 is assumed as a benchmark. Table 1 shows contractor tender capacity against registration grade regulated by CIDB (CIDB 2016, p.68, Lampiran 3).

Table 1 Contractor Registration Criteria based on (CIDB 2016, p.68, Lampiran 3)

\begin{tabular}{ccc}
\hline Grade of Registration & Tender Capacity (RM) \\
G1 & Not exceeding & $200,000.00$ \\
G2 & Not exceeding & $500,000.00$ \\
G3 & Not exceeding $1,000,000.00$ \\
G4 & Not exceeding $3,000,000.00$ \\
G5 & Not exceeding $5,000,000.00$ \\
G6 & Not exceeding 10,000,000.00 \\
G7 & No limit \\
\hline
\end{tabular}

\subsection{LITERATURE REVIEW}

Building works are defined as the construction or erection or assembly related to a building or any other structure for the same purpose (HM Government, n.d.). Civil infrastructure is the basic amenities that involve the construction of roads, water supply, drainage, sewerage and others that form a physical system. According to New Zealand Quality Authority (NZQA, 2014), civil infrastructure involves the construction and maintenance of infrastructure assets such as road, earthwork, utilities, etc.

Average preliminaries for building works are in a range of 3.60\% and 7.94\% (Keng et al., 2012; Keng, 2016). On the other hand, Ghani (Ghani, 2006) found that the preliminaries were between 5\% and 10\%. By comparing, the lowest percentage limit was significantly reduced by $28 \%$. In general, preliminaries for Malaysian building works is expected not to exceed $10 \%$ of the tender sum (Ghani, 2006 ; Turner \& Townsend, 2016).

Preliminaries are crucial and constitute part of the contractor's profit margin consideration. In Malaysia, the typical profit margin for a medium commercial scale is $12.5 \%$ (Turner \& Townsend, 2016). Poor preliminaries will certainly reduce the margin due to under estimation of intangible costs. Azman, Abdul Samad and Ismail (Azman et al., 2013) said that under estimation would lead to project failure, such as the abandonment of project, a possible lawsuit, etc. Jimoh and Adama (Jimoh et al., 2011) reminded that the percentage of preliminaries are very much affected by the project nature and site constraints. Preliminaries are crucial due to the uncertainty of the project requirements.

A recommendation established a decade ago by Boussabaine (Boussabaine, 2007) may be tested for its relevance to the present situation. Boussabaine said the Preliminaries for highly restricted or confined areas warrants an extra cost of 50\% above the average due to extra resources or special techniques required. However, the geographical factor such as sloping terrain or poor soil condition would incur additional $23 \%$ of the average cost of preliminaries (Boussabaine, 2007).

\subsection{RESEARCH METHODOLOGY}

Content analysis encompassing the preliminaries bills for civil works and statistical analysis was applied. 25 tender evaluation documents from six separate tender exercises between 2011 and 2015 for civil infrastructure projects in Klang Valley, Malaysia were analysed. The documents were previously shortlisted for consideration in the tender evaluation stage. For sampling purposes, one tender evaluation document represents one contractor. Table 2 shows a total of 25 tender evaluation documents for civil infrastructure works obtained from six tender evaluation exercises in Klang Valley for a period of 2010-2015 (Abas, 2016, p.54, Table 5.1).

Table 2 Tender evaluation documents for civil infrastructure works (Abas, 2016, p.54, Table 5.1)

\begin{tabular}{cccc}
\hline Tender Evaluation Exercise & Type of Works & Tender Evaluation Document & Year of Tender \\
Tender 1 & Earthwork & 3 & 2010 \\
Tender 2 & Road \& Drain & 3 & 2015 \\
Tender 3 & Road \& Drain & 5 & 2015 \\
Tender 4 & Main Infra & 5 & 2012 \\
Tender 5 & Sewerage & 4 & 2014 \\
Tender 6 & Main Infra & 5 & 2011 \\
& & &
\end{tabular}

The appropriate sample sizes acceptable for the survey are between 30 and 500 (Rahim et al., 2014; Roscoe, 1975). Despite that, Hill \& Roscoe (Hill, 1998; Roscoe, 1975) suggested 10 to 20 samples would be sufficient for tight controls situation. Considering the documents 
used for this study are confidential and under strict use, the 25 tender evaluation documents obtained from six tender evaluation exercise were within this ambit and therefore the sample population was considered sufficient.

Firstly, the average preliminaries for civil infrastructure was established and compared to previous research findings of building works. Secondly, the average civil infrastructure preliminaries was further analysed by statistical analyses using Boussabaine's (Boussabaine, 2007) and standard deviation method to establish the most reliable results.

\subsection{FINDINGS AND DISCUSSIONS}

Table 3 shows tabulation of the lowest and highest percentages of preliminaries for the tender evaluation exercises with their averages and differences used by Abas (Abas, 2016, P.58, Table 5.3). The preliminaries were priced with an average difference of $3.44 \%$ between contractors, despite tendering the same project that shared common requirements and constraints. Reference to the lowest and the highest percentages showed that the contractors' bid ranges between $1.05 \%$ and $9.37 \%$ of the tender sum. Despite that, the average civil infrastructure preliminaries were between $3.44 \%$ and $6.88 \%$.

Table 3 Percentage of preliminaries against tender sum (Abas, 2016, p.58, Table 5.3)

\begin{tabular}{ccccc}
\hline Tender Evaluation Exercise & Lowest & Average & Highest & $\begin{array}{c}\text { Difference } \\
\text { (Highest - Lowest) }\end{array}$ \\
Tender 1 & $4.84 \%$ & $6.06 \%$ & $7.19 \%$ & $2.34 \%$ \\
Tender 2 & $4.55 \%$ & $5.73 \%$ & $7.01 \%$ & $2.46 \%$ \\
Tender 3 & $3.27 \%$ & $4.95 \%$ & $8.48 \%$ & $5.21 \%$ \\
Tender 4 & $2.21 \%$ & $3.23 \%$ & $4.36 \%$ & $2.15 \%$ \\
Tender 5 & $4.73 \%$ & $6.36 \%$ & $9.37 \%$ & $4.65 \%$ \\
Tender 6 & $1.05 \%$ & $2.62 \%$ & $4.88 \%$ & $3.83 \%$ \\
Average & $\mathbf{3 . 4 4 \%}$ & $\mathbf{4 . 8 2 \%}$ & $\mathbf{6 . 8 8 \%}$ & $\mathbf{3 . 4 4 \%}$ \\
\hline
\end{tabular}

Comparison of preliminaries between civil infrastructure i.e. $3.44 \%$ and $6.88 \%$ and building works i.e. $3.60 \%$ and $7.94 \%$ opined by Keng and Ching (Keng et al., 2012; Keng, 2016) revealed the variants between $4 \%$ and $13 \%$ respectively. It was noted that the average preliminaries of the building work was slightly higher than the civil infrastructure but both did not exceed 10\% (Ghani, 2006; Turner \& Townsend, 2016). However, the lowest limits were less than 5\% for both cases. Hence, the 5\% limit established by Ghani (Ghani, 2006) is no longer justified for the present situation. The finding shows the average percentage of civil infrastructure preliminaries was $8.5 \%$ lower than that of building works.

Preliminaries are influenced by site constraints. For the samples size, the project sites were situated in the non-restricted areas. Assuming that the slopes and poor soil condition were the constraints, therefore as suggested by Boussabaine (Boussabaine, 2007), the tolerance of $\pm 23 \%$ of the average preliminaries may be adopted. Based on this assumption, the average tolerance of $1.11 \%$ was therefore established.

Table 4 shows the derivation of average tolerance equals to $\Sigma$ (Addition @ 23\% of preliminaries) $\div 6$ (Abas, 2016, p.63, Table 5.7).

Table 4 Derivation of tolerance based on boussabaine's (Abas, 2016, p.63, Table 5.7)

Tender Evaluation Exercise

Tender 1
Tender 2
Tender 3
Tender 4
Tender 5
Tender 6
Average
Average Preliminaries \%

$6.06 \%$

$5.73 \%$

$4.95 \%$

$3.23 \%$

$6.36 \%$

$2.62 \%$

$4.82 \%$
Addition@ $23 \%$ of Preliminaries

$1.39 \%$

$1.32 \%$

$1.14 \%$

$0.74 \%$

$1.46 \%$

$0.60 \%$

$1.11 \%$

Table 5 shows the higher and lower limits of preliminaries adopting the tolerance derived from Boussabaine's. As such average percentages of the civil infrastructure preliminaries were between $3.71 \%$ and $5.93 \%$ based on Limit of Preliminaries $=$ Average Preliminaries $\pm 1.11 \%$.

Table 5 Limit of preliminaries based on tolerance derived from Boussabaine's

$\begin{array}{cc}\text { Preliminaries } & \text { Percentage (\%) } \\ \text { Higher limit } & 5.93 \% \\ \text { Average } & \mathbf{4 . 8 2 \%} \\ \text { Lower limit } & 3.71 \%\end{array}$


Further verification on Boussabaine's using standard deviation method was carried out. Table 6 shows the derivation of standard deviation based on the average preliminaries of six tender evaluation exercises as established by Abas (Abas, 2016, p.64, Table 5.8).

Table 6 Establishment of standard deviation for percentage of preliminaries of civil infrastructure works (Abas, 2016, p.64, Table 5.8)

\begin{tabular}{cccc}
\hline Tender Evaluation Exercise & Average & Mean & Difference \\
Tender 1 & $6.06 \%$ & & $1.23 \%$ \\
Tender 2 & $5.73 \%$ & $0.91 \%$ & $0.12 \%$ \\
Tender 3 & $4.95 \%$ & $4.82 \%$ & $-1.60 \%$ \\
Tender 4 & $3.23 \%$ & $0.008 \%$ & $1.54 \%$ \\
Tender 5 & $6.36 \%$ & $-2.20 \%$ & $0.025 \%$ \\
Tender 6 & $2.62 \%$ & $0.024 \%$ & Average Variance \\
& & $0.024 \%$ & Standard Deviation $\boldsymbol{\delta}$ \\
\hline
\end{tabular}

Standard deviation is derived based on Equation (1).

$\begin{array}{lll}\begin{array}{l}\text { Population, } \\ \text { Average variance }\end{array} & & \\ & = & \frac{0.121}{5} \\ & & \\ & = & 0.024 \\ \text { Standard deviation } \delta & = & \sqrt{ } 0.024 \\ & = & \mathbf{1 . 5 6}\end{array}$

Hence, the modified percentage of civil infrastructure preliminaries was between $3.26 \%$ and $6.38 \%$ calculated based on the Limit of Preliminaries $=$ Mean $\pm 1.56 \%$. Table 7 shows the higher and lower limits of civil infrastructure preliminaries derived based on standard deviation (Abas, 2016, p.64, Table 5.9).

Table 7 Limit of preliminaries using standard deviation (Abas, 2016, p.64, Table 5.9)

\begin{tabular}{cc}
\hline Preliminaries & Percentage (\%) \\
Higher limit & $6.38 \%$ \\
Mean & $\mathbf{4 . 8 2 \%}$ \\
Lower limit & $3.26 \%$ \\
\hline
\end{tabular}

In comparison, the variations in both approaches were within $0.5 \%$. Table 8 indicates civil infrastructure preliminaries as derived from Boussabaine's and standard deviation were comparable, therefore generally accepted (Abas, 2016, p.64, Table 5.10). However, the tolerance provided by Boussabaine's is more stringent as compared to standard deviation.

Table 8 Comparison between boussabaine's and standard Deviation (Abas, 2016, p.64, Table 5.10)

\begin{tabular}{|c|c|c|c|}
\hline & Boussabaine's & Standard Deviation $\boldsymbol{\delta}$ & Variation \\
\hline Higher limit & $5.93 \%$ & $6.38 \%$ & $0.45 \%$ \\
\hline Lower limit & $3.71 \%$ & $3.26 \%$ & $0.45 \%$ \\
\hline
\end{tabular}

The author suggests standard deviation approach would result in a wider tolerance for the lower and higher limits of the preliminaries against tender sum. Standard deviation is reliable for the Statistical Analysis that deals with uncertainties (IPCC, 2000). Boussabaine's (Boussabaine, 2007) may provide a rule of thumb basis for consideration; however, the tolerance provided by Boussabaine's is narrower compared to the standard deviation method, and therefore more stringent. The author has the opinion that the standard deviation method would be more reliable for adoption.

Based on this approach, a comparison between the preliminaries of building and civil infrastructure works is carried out to verify the variation quantum in terms of percentage. Table 9 shows the differences of preliminaries between both types of works. 
Table 9 Comparison between preliminaries of building and civil infrastructure works

Building Work

(Keng et al., 2012; Keng, 2016)

\begin{tabular}{c}
$\begin{array}{c}\text { Higher limit } \\
\text { Lower limit }\end{array}$ \\
\hline Average
\end{tabular}

$7.94 \%$

$3.60 \%$

$5.77 \%$
Civil Infrastructure Work based on

Standard Deviation $\boldsymbol{\delta}$

$6.38 \%$

$3.26 \%$

$4.82 \%$

$1.56 \%$

$0.34 \%$

$0.95 \%$

The variation of percentages between the building work and civil infrastructure work is $0.95 \%$, hence based on the following calculation, the preliminaries for civil infrastructure work constitutes some $16.5 \%$ lower than the building work.

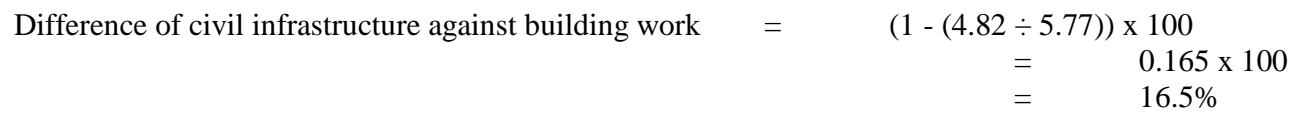

\subsection{CONCLUSION}

In conclusion, preliminaries for the civil infrastructure and building works are between $3 \%$ and $10 \%$. As such the limits of 5\% and $10 \%$ (Ghani, 2006) are no longer relevant for the present situation. The study found that the percentage difference between the civil infrastructure preliminaries and building works do exist. Standard deviation provides a wider tolerance for the lower and higher limits of the preliminaries against tender sum. Civil infrastructure preliminaries are lower by some $16.5 \%$ compared to the building works. The study concludes that the average preliminaries for the infrastructure works were between $3.26 \%$ and $6.38 \%$.

\section{References}

Abas, A. A. (2016). Variation in Price of Preliminaries in Construction Projects During Tender Stage. Universiti Teknologi MARA, Shah Alam, Malaysia.

Azman, M. A., Abdul-Samad, Z., \& Ismail, S. (2013). The Accuracy Of Preliminary Cost Estimates In Public Works Department (PWD) of Peninsular Malaysia. International Journal of Project Management, 31(7), 994-1005. http://doi.org/10.1016/j.ijproman.2012.11.008

Boussabaine, A. (2007). Cost Planning of PFI and PPP Building Projects. London \& New York: Taylor \& Francis. Retrieved from https://books.google.com.my/books?id=zUUrBgAAQBAJ\&pg=PR15\&lpg=PR15\&dq=Cost+Planning+of+PFI+and+PPP+Building+Projects\&source=bl\&ots $=$ KzJvB_M0Ym\&sig=dwpZ-ps3jrRAeSzww7QHjjIJWW0\&hl=en\&sa=X\&redir_esc=y\#v=onepage\&q=Cost Planning of PFI and PPP Building Projects

CIDB. (2016). Contractor Registration Requirements and Procedures. Construction Industry Development Board (CIDB) Malaysia. Retrieved from http://www.cidb.gov.my/cidbv5/images/content/Kontraktor/lampiran-4---Full.pdf

Ghani, N. A. (2006). The importance of preliminaries items. Universiti Teknologi Malaysia. Retrieved from http://eprints.utm.my/216/4/NorhishamAbdGhaniMAD2006TTTCHAP1.pdf

Hill, R. (1998). What Sample Size is “ Enough” in Internet Survey Research? Nterpersonal Computing and Technology: An Electronic Journal for the 21st Century, 6(3), 1-10. Retrieved from http://www.reconstrue.co.nz/IPCT-J Vol 6 Robin hill SampleSize.pdf

HM Government. (n.d.). The Building Regulations 2010. Approved Document L2B: Conservation of Fuel and Power in Existing Buildings Other than Dwellings, $5,5$. Retrieved from http://www.planningportal.gov.uk/uploads/br/BR_PDF_AD_L2B_2011.pdf

IPCC. (2000). Conceptual Basis for Uncertainty Analysis. IPCC Good Practice Guidance and Uncertainty Management in National Greenhouse Gas Inventories. Retrieved from http://www.ipcc-nggip.iges.or.jp/public/gp/english/A1_Conceptual.pdf

Jimoh, R. A., \& Adama, S. M. (2011). Assessment of Preliminaries In Relation To The Total Cost Of Renovation Work In Public Schools In Abuja, Nigeria. In ICEC IX World Congress Assessment (pp. 1-9). Retrieved from https://www.academia.edu/10892594/Assessment_Of_Preliminaries_In_Relation_To_The_Total_Cost_Of_Renovation_Work_In_Public_Schools_in_Abuja_ Nigeria?auto $=$ download

Keng, T. C. (2016). Costing for The Preliminaries Section of The Construction. In M. F. A. Ayob \& M. S. Ibrahim (Eds.), Cost and Contract Administration in Construction, Devine Perspectives,1(1), 24-29. Kuala Lumpur: IIUM Press. Retrieved from http://irep.iium.edu.my/31609/1/31609_Costing_For_The_Preliminaries_Section_Chapter.pdf

Keng, T. C., \& Ching, Y. K. (2012). A Study on The Cost of Preliminaries Section in Construction Projects, (1), 1-6.

NZQA. (2014). CIVIL INFRASTRUCTURE HEALTH , SAFETY, AND ENVIRONMENT - Describe protection Of Health , Safety And Environment In The Civil Infrastructure Industry. Retrieved from http://www.nzqa.govt.nz/nqfdocs/units/pdf/20870.pdf

Rahim, N. M., Mohd Yusoff, S. H., \& Abd Latif, S. (2014). Assessing Readiness for E-Learning among Students of Universiti Selangor. Australian Journal of Basic and Applied Sciences, 8(20), 11-14. Retrieved from http://ajbasweb.com/old/ajbas/2014/Special 14/11-14.pdf

Roscoe, J. T. (1975). Fundamental Research Statistics For The Behavioral Sciences [by] John T. Roscoe (2nd ed.). New York: Holt, Rinehart and Winston.

Turner \& Townsend. (2016). International construction Market Survey 2016. Retrieved from http://www.turnerandtownsend.com/media/1518/internationalconstruction-market-survey2016.pdf 